УAK 552.513.1:553.981.2

\title{
Y.V. Antipovich
}

THE TRANSFORMATION OF CARBONIC SANDSTONE POROSITY OF THE DONBAS

\author{
Я.В. Антіпович \\ ПЕРЕТВОРЕННЯ ПОРИСТОСТІ КАРБОНОВИХ ПІСКОВИКІВ АОНБАСУ
}

Fuel and power complex of the country is in need for alternative energy sources, where methane being found in coal deposits can be considered as one in the range. The Donets Basin is a perspective area for extracting coalbed methane in the terms of energy resources concomitant. In order to evaluate the possibility of developing the Donbass as a coal gas deposit with complex exploitation it is needed extra research of reservoir rock properties. Previously established regularities of transforming open porosity and volume density of sandstones are of great practical importance, and are the basis for further studies of reservoir rock properties. In this paper, particular attention was paid to the study of transformations of sandstones closed porosity. To observe the transformation process of rocks closed porosity caused by changing conditions was used microscopic method is one of the applied ones giving the possibility to observe gas inclusions in clastic mineral grains at high magnification (from 100 to 1200 power with the use of immersion liquid). Presumably, these gas inclusions are a part of closed porosity so it is suggested to divide the closed porosity into the cement-closed porosity and mineralogical closed porosity. Mineralogical closed porosity can serve as an indicator of rocks transformation grade and the study of gas inclusion transformation taken place in sandstone quartz grains provides the partial answer to the issue of changing gas component in the rocks pore space with increasing rocks catagenesis stage. Keywords: catagenesis, sandstone, gas inclusions, closed porosity, quartz grains.

Паливно-енергетичний комплекс України потребує альтернативних енергетичних ресурсів, одним з яких $є$ метан вугільних родовищ. Перспективним районом видобутку вугільного газу як енергетичної сировини є Аонецький басейн. Аля того, щоб оцінити можливість розробки Аонбасу, як комплексного газовугільного родовища, необхіАні Аодаткові АосліАження колекторських властивостей поріА. Отримані раніше вченими закономірності зміни об'ємної щільності та відкритої пористості поріА басейну, є фундаментальними і лягають в основу подальших АосліАжень. У Ааній роботі особливу увагу було приАілено АосліАженню перетворень закритою пористості пісковиків. А^я того, щоб простежити процес перетворення закритої пористості поріА піА Аією змінюющихся умов був застосований мікроскопічний метоА АосліАження, за Аопомогою якого, при великих збільшеннях (віА 100 до 1200 крат із застосуванням імерсійної рідини) були вивчені газоріАинні включення в уламкових зернах мінералів. Оскільки, імовірно, дані включення являють собою частину закритою пористості запропоновано розділяти закриту пористість на цементну і мінералогічну. Мінералогічна закрита пористість, може служити як індикатор ступеня перетворення поріА, а досліАження трансформацій газових включень в кварцових зернах пісковиків частково віАповісти на питання про зміну газової складової порового простору поріА зі збільшенням стадії катагенезу.

Ключові слова: катагенез, пісковик, газові включення, закрита пористість, кварцові зерна.

\section{INTRODUCTION}

Providing Ukraine by its own energy resources is an urgent problem for the country's power sector. As it is known, natural gas is considered to be one of the main power resources. Its share in the country's power balance is $41-43 \%$. Ukraine is referred to the countries with hydrocarbon production shortage and is capable to satisfy the demand for natural gas only up to $23-25 \%$. Therefore, fuel and power complex of the country is in need for alternative energy sources, where methane being found in coal deposits can be considered as one in the range.

The Donets Basin is a perspective area for extracting coalbed methane in the terms of energy resources concomitant. By different estimations the total volume of methane content in coal mass of the Donets Basin at depths from 500 to $1800 \mathrm{~m}$ varies from 12 to 25 trillion $\mathrm{M}^{3}$. According to the scientists' point of view, this basin should be considered as a coal gas deposit with complex exploitation to reduce gas emissions into mine workings and obtain unconventional type of gas materials at an industrial scale as well (Airuni et al., 1990; Zhikalyak, 2002).

\section{OBJECT, AIM AND THE METHOD OF RESEARCH}

Reservoir properties of rocks are the main parameters used for developing and producing hydrocarbon accumulations. As for the Donets Basin the study of reservoir properties of gas-bearing rocks in terms of the main parameter while prospecting and developing hydrocarbon accumulations was not carried out in full volumes and in a greater or lesser degree was associated with forecasting gasdynamic events taking place in coal mines.

Sandstones are the main collectors of free gas in the Donets Basin. They are associated with gas accumulations of industrial significance and the numerous micro accumulations of free gas. Despite this, the gas production is associated with a number of difficulties. The main reason is the complex 
mining and specific geological conditions of basin deposits, which had a significant impact on increasing mining rocks density and promoted decreasing porosity and permeability of the mining rocks.

The main aim of our research is investigation of catagenesis influence on reservoir properties of sandstones of the Donbas. In order to solve this task used previously received materials about the study of open porosity and density of sandstone and also carried out additional studies of the closed porosity sandstones to establish forms of gas finding in the rock.

To investigate the closed porosity used microsections of sandstones which samples were taken within the different stages of catagenesis. Microsections were examined using an optical microscope at high magnification (from 100 to 1200 power with the use of immersion liquid).

\section{RESULTS OF RESEARCHES AND THEIR ANALYSIS}

Early studies of reservoir parameters, physical, mechanical, sorption properties and petrographic characteristics of sandstones showed that catagenesis processes had a significant impact on the values of these indicators (Zabigaylo et al., 1983). Therefore, while studying rocks reservoir properties their paleodepth should be considered as an indicator of catagenesis grade.

Porosity, permeability, density and pore saturation by fluids are the main features characterizing the quality of rocks-collectors. The complex of these parameters determines the reservoir properties of rocks.

Porosity is the amount of syngenetic (primary) and epigenetic (secondary) cavitations in the rock. It is divided into the absolute porosity (a total volume of all cavitations irrespective of their shape, size and relative position), the open porosity (the complex of interconnected set of pores and cavitations, the volume of the porosity (where the movement of liquid and gas under specific temperature and pressure is possible), and closed porosity (the complex of closed and isolated pores).

As for the conditions of the Donbas, the scientists focused their attention on investigating open porosity and density of the sandstones to predict rocks outburst. These parameters were studied depending on the genetic characteristics of sandstones, mineralogical and structural transformations, paleodepth influence and basin tectonics.

The general regularity of decreasing sandstone open porosity due to increasing catagenesis grade was determined in all areas of the Donbas. The most intensive decrease in the values of open porosity is typical for sandstones of early stage of catagenesis. With each subsequent sub-step transformation the range of open porosity changes is significantly reduced. This is due to the fact that increasing transformation degree causes rocks to consolidate and leads to decreasing the volumes of their pore space (Fig.1).

Regional tectonic processes forming the modern structural plan of the Donets Basin had significant impact on the change of reservoir rock properties. Moving from peripheral areas to the central part of the basin such cases as increasing volume density and decreasing open porosity of one lithogeneous type of the sandstones are observed. The sandstones in the central area are the most consolidated and have the lowest values of porosity and permeability (Zabigaylo et al., 1984).

Thus, such three factors as: the formation conditions defined by sandstone lithogeneous type, rocks paleodepth estimated by adjacent coal grade and tectonics characterized by sandstone position in a various structural zone had a significant impact on changes in volume density and open porosity. Previously established regularities of transforming open porosity and volume density of sandstones are of great practical importance, and are the basis for further studies of reservoir rock properties.

There was not enough attention to the research of closed porosity in conditions of the Donets Basin. The given task was considered not to have practical or scientific interest because of the absence of possibility to provide the movement of liquids and gases within the closed porosity.

Closed porosity of rocks is determined as the difference between absolute and open porosity. Obtaining the value of closed porosity by calculation we can define the general tendencies of the index changes. To observe the transformation process of rocks closed porosity caused by changing conditions the additional research methods are required. Microscopic method is one of the applied ones giving the possibility to observe gas inclusions in clastic mineral grains at high magnification (from 100 to 1200 power with the use of immersion liquid). This allows us to divide the closed porosity into the cement-closed porosity (the volume of closed porosity contained in the cement-grouted rock material) and mineralogical closed porosity (the volume of gas inclusions in clastic rock grains).

We can observe singular gas inclusions (primary inclusions), (Fig. 4a) and Boehm lamellae (secondary inclusions), (Fig. 4b) in sandstone quartz grains of the Donbas. 


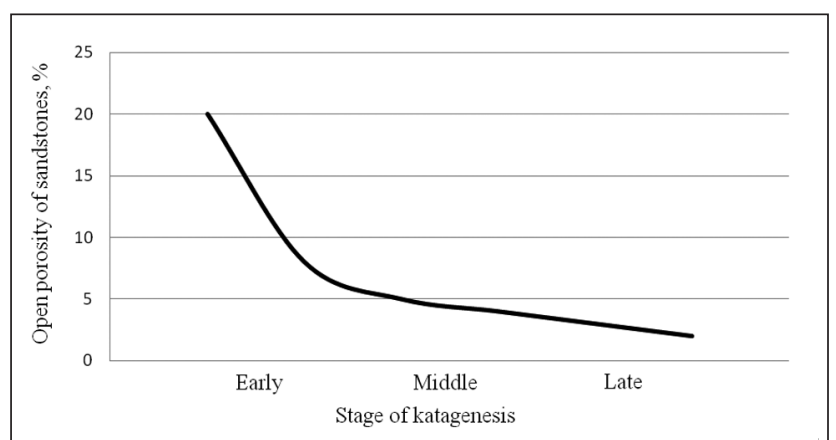

Fig. 1. Changing the value of open porosity with increasing rocks catagenesis stage (Airuni et al., 1990).

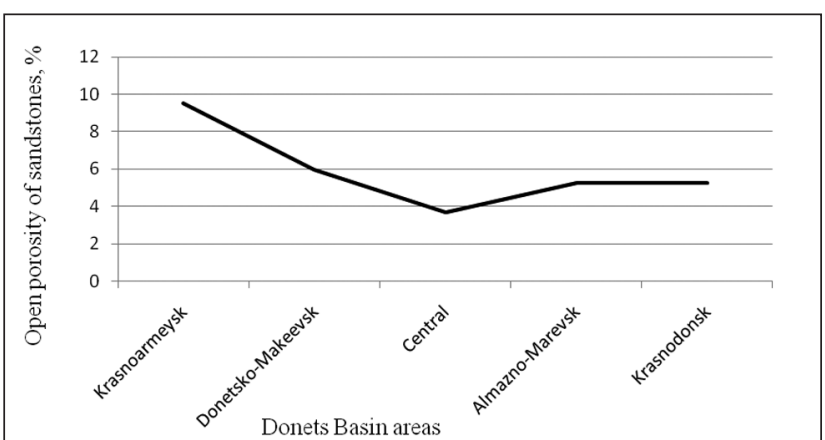

Fig. 2. Changing the value of sandstones open porosity depending on regional location in the basin (Zabigaylo et al., 1984).

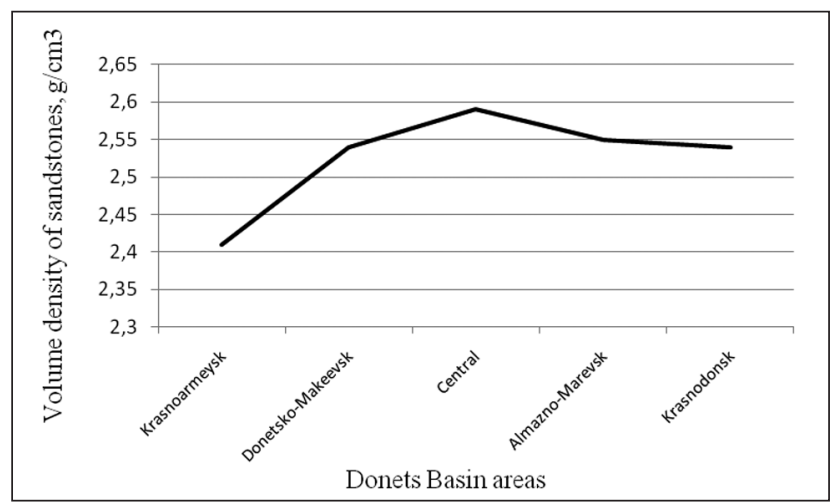

Fig. 3. Changing the value of sandstones volume density depending on regional location in the basin (Zabigaylo et al., 1984).
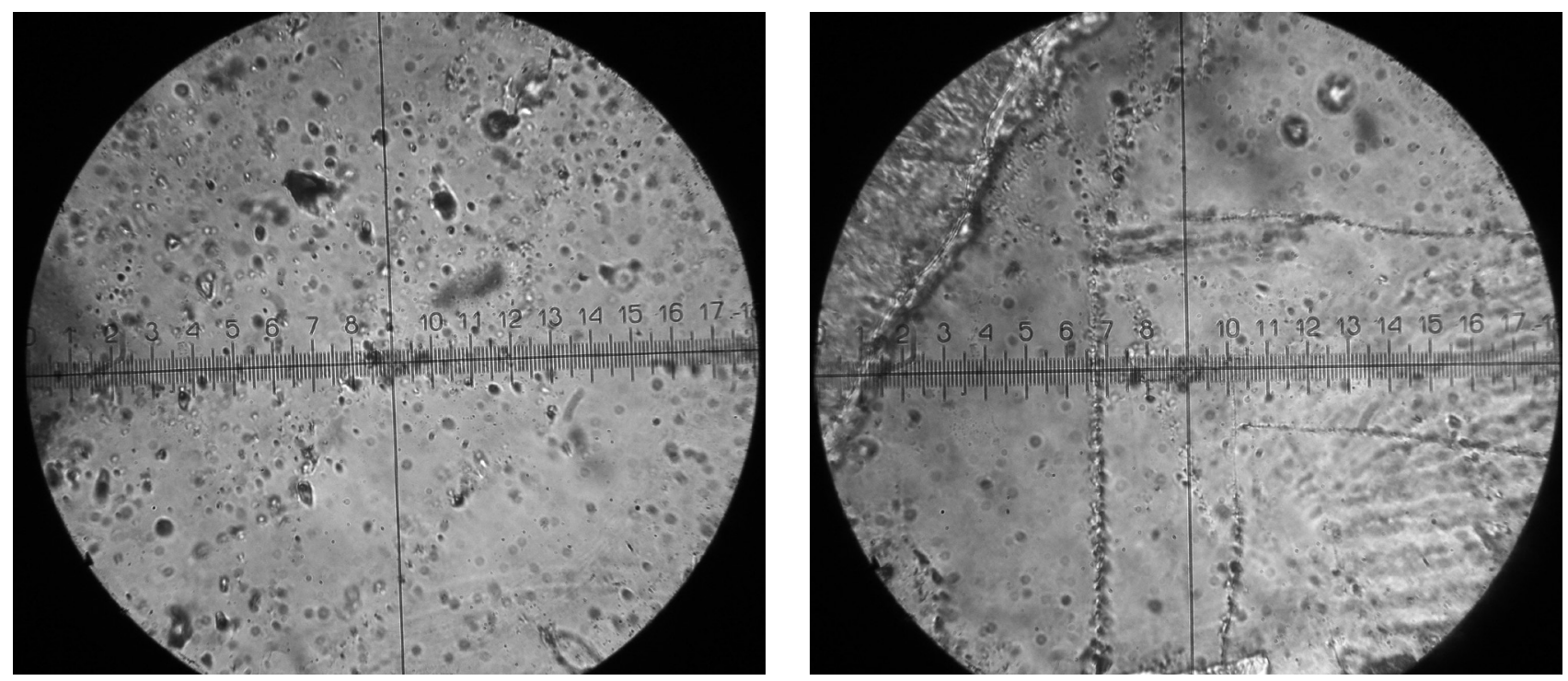

Fig. 4. Microsection of sandstone $\mathrm{I}_{3}{ }^{1} \mathrm{SI}$, mine named after A.G. Stakhanov, depth selection 794,0 m: a - singular gas inclusions in quartz grains, magnification 1200x; 6 - Boehm lamellae in quartz grains, magnification 1200x.

Boehm lamellae are microstructural deformations of sandstone quartz grains decorated with gas inclusions. They are of particular interest because previously their formation was proved to occur during rock catagenesis directly in the conditions of the
Donets Basin unlike the single gas inclusions formed in the source rocks (Baranov, 1989). The prevailing development of Boehm lamellae in sandstone quartz grains is explained by increased gas content formed during the process of coal incarbonisation and dis- 
persed organic matter in sedimentary rocks. Singular gas inclusions and Boehm lamellae are observed throughout the sandstone quartz grains of early and middle stages of catagenesis.

The studies of sandstone quartz grains at the late catagenesis stage demonstrated that increasing rocks transformation grade occured simultaneously with differentiating gas inclusions to the smallest size. In other words, sandstone paleodepth causes the inclusion form transformation, size reduction, and pressure stabilization.

\section{CONCLUSION}

The transformation process of the sandstones under catagenesis impact significantly influenced on

\section{REFERENCES:}

Airuni A.T., Galazov R.A., Sergeyev I.V., Kaledin L.M., Zenkovich V.A., Bobin B.A., Zaburdaev V.S., 1990. Gas content of coal mines of the USSR. Comprehensive development of gas-bearing coal deposits. Moscow, Science, 37 p. (In Russian).

Baranov V.A., 1989. Micro disturbance of quartz sandstones of Donbas in connection with their outburst: Dissertation abstract for candidate of Geological Sciences : specialty 04.00.16 «Geology, prospecting and exploration of solid fuels". Dnepropetrovsk, p. 12. (In Rissian).

Zhikalyak M.V., 2002. Coalbed methane in the local energy of the Donbas. Geotechnical Mechanics, №32, 74 p. (In Russian).

Zabigaylo V.E., Lukinov V.V., Shirokov A.Z., 1983. Outburst of rocks of Donbass. Kiev, Naukova Dumka, 185 p. (In Russian).

Zabigaylo V.E., Lukinov V.V., 1984. Investigation of regularities of changes the material composition, structure, properties and gas-bearing rocks and coals according to the depth of occurrence; improvement and implementation of methods for forecasting outburst rocks and coal beds in geological prospecting: Report of the scientific-research work (annual). Institute of Geotechnical Mechanics of National Academy of Science of Ukraine, Dnepropetrovsk, p. 137. Inv. No 3522 (In Rissian).

Yana_Antipovich@ukr.net reservoir properties of these rocks. Increasing of catagenesis stage leads to the result that the open porosity of sandstones is reduced. During this process part of the gas passes from the open pores to microstructural deformations of sandstone quartz grains and forms a closed porosity. The study of closed porosity complements the classical methods applied to determine rocks reservoir properties and is of a specific practical concern. Mineralogical closed porosity can serve as an indicator of rocks transformation grade and the study of gas inclusion transformation taken place in sandstone quartz grains provides the partial answer to the issue of changing gas component in the rocks pore space with increasing rocks catagenesis stage.

Газообильность каменноугольных шахт СССР. Комплексное освоение газоносных угольных месторождений / [А. Т. Айруни, Р. А. Галазов, И. В. Сергеев, Н.В. Каледин, А.М. Зенкович, В.А. Бобин, В.С. Забурдаев]. - Москва: Наука, 1990. - 216 C.

Баранов В. А. Микронарушенность кварца песчаников Аонбасса в связи с их выбросоопасностью : автореф. Аис. на соиск. учен. степени канд. геол.-мин. наук : спец. 04.00.16 «Геология, поиски и развеАка месторожАений твердых горючих ископаемых" / Баранов В. А. - Анепропетровск, 1989. - 17 с.

Жикаляк М. В. Метан угольных месторождений в ^окальной энергетике Аонбасса / М. В. Жикаляк. // Геотехническая механика. - 2002. - №32. - С. 74-76.

Забигайло В. Е. Выбросоопасность горных пород Аонбасса / В. Е. Забигайло, В. В. Аукинов, А. З. Широков. Киев: Наукова Аумка, 1983. - 287 с.

Иследование закономерности изменения вещественного состава, структуры, свойств и газоносности горных пороА и углей в зависимости от глубины залегания; усовершенствование и внеАрение методов прогноза выбросоопасности пород и угольных пластов при геологоразведочных работах: отчет о НИР (гоАОвой) / ИГТМ НАН Украины; рук. В.Е. Забигайло; исполн. В.В. Аукинов [и Ар.]. - Анепропетровск, 1984. - 137 с. - Инв. №3522.

Рецензент: В.А.Баранов 